\title{
PENGARUH KEPEMIMPINAN TRANSFORMASIONAL DAN IKLIM PSIKOLOGIS TERHADAP KESIAPAN UNTUK BERUBAH KARYAWAN PUSKESMAS KABUPATEN LOMBOK BARAT DALAM RANGKA AKREDITASI DAN KOMITMEN AFEKTIF SEBAGAI VARIABEL INTERVENING
}

Oleh:

\author{
Mujiburrahman ${ }^{1}$ \\ Thatok Asmony ${ }^{2}$ \\ Hamdani Husnan ${ }^{2}$
}

\begin{abstract}
This research is aimed at determining the significant effect of: (a) transformational leadership on readiness to change of employees of Health Centers in West Lombok. (b) transformational leadership on the affective commitment. (c) transformational leadership on the readiness to transform through affective commitment. (d) the psychological circumstances on preparedness to transform. (e) the psychological circumstances on affective commitment. (f) the psychological circumstances on preparedness to transform through the affective commitment of employees of Health Centers in West Lombok, $(g)$ affective commitment of employees of health centers in West Lombok on preparedness to transform. This research is a causal associative with population of 508 employees of 7 health centers from which 84 employees are selected as samples through random sampling technique. The research showed that: (a) Transformational Leadership had no significant effect on readiness of employees of Health Centers in West Lombok to transform, (b) there is a significant effect of transformational leadership on affective commitment. (c) there is a significant effect transformational leadership on readiness to transform through affective commitment. (d) there is a significant effect of the psychological circumstances on readiness to transform. (e) there is a significant effect of the psychological circumstances on affective commitment. ( $f$ ) there is a significant effect of the psychological circumstances on readiness to transform through affective commitment. ( $g$ ) There is a significant effect of Affective Commitment to Readiness of employees of Health Centers in West Lombok to transform.
\end{abstract}

Keywords: transformational leadership, psychological circumstance, commitment, individual readiness to transform

\section{PENDAHULUAN}

Kesiapan individu dalam menghadapi perubahan menjadi hal penting yang harus diperhatikan dalam setiap proses perubahan. Hal tersebut karena kesiapan individu untuk berubah mampu menjembatani strategi manajemen perubahan dengan keluaran yang diharapkan, yaitu kesuksesan implementasi strategi (Palmer et al., 2009). Menurut Trahat dan Burke (1996, dalam Cinite et al., 2009), konteks organisasional seperti struktur organisasi, strategi, sistem, kebijakan dan prosedur, teknologi, gaya kepemimpinan dan praktik manajerial merupakan anteseden dari kesiapan untuk berubah.

Pada penelitian Santhidran, et.al (2010), bahwa hasil penelitian menunjukkan kepemimpinan transformasional berpengaruh positif dan signifikan terhadap kesiapan berubah. Sedangkan pada penelitian Hasanah (2016) mebuktikan bahwa kepemimpinan transformasional berpengaruh positif namun tidak signifikan terhadap kesiapan untuk berubah. Namun sebaliknya Zulkarnain dan Hadiyani (2014) dan Suryati (2016) serta Yuni 
(2014) dalam penelitiannya membuktikan bahwa kepemimpinan transformasional berpengaruh signifikan terhadap kesiapan untuk berubah.

Selain dipengaruhi oleh kepemimpinan, kesipan untuk berubah juga dipengaruhi oleh iklim psikologis. Menurut McNabb dan Sepic (dalam Periantolo dan Mansoer, 2014), iklim psikologis merupakan variabel yang dapat memprediksi kesiapan untuk berubah. Pendapat tersebut dipertegas oleh penelitian Periantolo dan Mansoer, (2014) serta Hasanah (2016), bahwa iklim psikologis berpengaruh terhadap kesiapan untuk berubah. Sedangkan penelitian Anggi (2014), sangat kecil kontribusi pengaruh variabel independen kepada variabel dependen. Oleh karena itu penulis mengindikasikan variabel lain yang dapat memperkuat kesiapan individu untuk berubah adalah variabel komitmen afektif yang ada pada diri individu terhadap organisasi. Martin, dkk (2005), menyatakan bahwa para pegawai yang mempersepsikan organisasi dan lingkungan kerja secara positif lebih mudah untuk mengikuti perubahan.

Selain kepemimpinan transformasional dan iklim psikologis, komitmen karyawan dapat juga berpengaruh terhadap kesiapan untuk berubah. Dimana dalam penelitian Zulkarnain dan Hadiyani (2014) dan Suryati (2016) membuktikan bahwa komitmen organisasi berpengaruh signifikan terhadap kesiapan untuk berubah. Sedangkan peneltian yang dilakukan oleh Yuni (2014), hasil penelitian bahwa komitmen organisasional memoderasi pengaruh gaya kepemimpinan transformasional terhadap kesiapan berubah.

Dari hasil telaah teori bahwa komitmen organisasi memiliki tiga dimensi yaitu komitmen afektif, komitmen berkelanjutan dan komitmen normative. Berdasarkan dari pengamatan awal terkait komitmen para pegawai Puskesmas yang terlihat secara dominan, para pegawai memiliki komitmen afektif, dimana para pegawai cenderung memiliki kedekatan emosional yang erat terhadap organisasi (Puskesmas). Hal ini berarti bahwa individu tersebut memiliki motivasi dan keinginan untuk berkontribusi secara berarti terhadap organisasi (Puskesmas). Saat ini semua Puskesmas yang ada di Kabupaten Lombok Barat telah mengusulkan adanya akreditasi dalam organisasi (Puskesmas) yang merupakan sebagai salah satu sarana atau tujuan yang harus dicapai suatu organisasi (pelayanan publik). Komitmen yang diberikan terhadap karyawan yaitu : "Menyatakan sanggup menyelenggarakan pelayanan yang telah ditetapkan dan akan melakukan secara terus menerus untuk dapat memberikan jaminan pelayanan yang lebih baik serta mematuhi dan mengimplementasikan standard dan instrumen akreditasi dalam pelayanan di UPT BLUD Puskesmas". (Sumber: Pergub No 18 Tahun 2016).

Pengamatan selanjutnya, dimana ciri-ciri gaya kepemimpinan yang dilakukan oleh kepala Puskesmas yaitu adanya ciri yang menonjol seperti inspirational motivation dimana kepala Puskesmas berperilaku dengan memberi motivasi inspirasi terhadap orang-orang (pegawai) disekitarnya. Kepala Puskesmas pandai dalam menyerukan visi masa depan, menantang para pegawai dengan standar kerja yang tinggi, berbicara secara optimis dan antusias, dan memberikan dorongan dan arti dari apa yang perlu dilakukan. Kemudian ciri yang kedua yaitu intellectual stimulation. Dalam hal ini kepala Puskesmas sebagai pemimpin menstimulasi usaha bawahannya (para pegawai) untuk berlaku inovatif dan kreatif seperti adanya cara kerja yang baru untuk mengefektifkan cara kerja yang lama dalam mengerjakan pekerjaan. Serta kepala Puskesmas dari setiap hasil kerja mempertanyakan asumsi para pegawai. Sedangkan pada ciri-ciri berikutnya yaitu attributed charisma. Dalam kepentingan organisasi, kepala Puskesmas mendahulukan kepentingan organisasi dan kepentingan orang lain dari kepentingan diri. Hal ini 
ditunjukan dengan adanya sepenuh waktu kepala Puskesmas masih berada di Puskesmas ketika jam kerja sudah selesai, dimana yang dikerjakan adalah memeriksa kembali suatu pekerjaan para pegawai melalui evaluasi kertas kerja para pegawai. Ini mengindikasikan sebagai pimpinan dalam organisasi bersedia memberikan pengorbanan untuk kepentingan organisasi (Puskesmas).

Adapun masalah penelitian dirumuskan sebagai berikut: :

1) Apakah Kepemimpinan Transformasional berpengaruh signifikan terhadap Kesiapan Untuk Berubah karyawan Puskesmas Kabupaten Lombok Barat.

2) Apakah Kepemimpinan Transformasional berpengaruh signifikan terhadap Komitmen Afektif karyawan Puskesmas Kabupaten Lombok Barat.

3) Apakah Kepemimpinan Transformasional berpengaruh signifikan terhadap Kesiapan Untuk Berubah melalui Komitmen Afektif karyawan Puskesmas Kabupaten Lombok Barat.

4) Apakah Iklim Psikologis berpengaruh signifikan terhadap Kesiapan Untuk Berubah karyawan Puskesmas Kabupaten Lombok Barat.

5) Apakah Iklim Psikologis berpengaruh signifikan terhadap Komitmen Afektif karyawan Puskesmas Kabupaten Lombok Barat.

6) Apakah Iklim Psikologis berpengaruh signifikan terhadap Kesiapan Untuk Berubah melalui Komitmen Afektif karyawan Puskesmas Kabupaten Lombok Barat.

7) Apakah Komitmen Afektif berpengaruh signifikan terhadap Kesiapan Untuk Berubah karyawan Puskesmas Kabupaten Lombok Barat.

\section{KERANGKA TEORITIS}

\subsection{Landasan Teori}

\section{a. Kesiapan Individu Untuk Berubah}

Holt, et.al (2007) mendefinisikan kesiapan individu untuk berubah adalah sebagai sikap komprehensif yang secara simultan dipengaruhi oleh isi (apa yang berubah), proses (bagaimana perubahan diimplementasikan), konteks (lingkungan dimana perubahan terjadi), dan individu (karakteristik individu yang diminta untuk berubah) yang terlibat di dalam suatu perubahan. Sedangkan Wibowo (2005) menyatakan bahwa kesiapan untuk berubah adalah mempersiapkan segenap sumber daya manusia untuk menerima perubahan, karena pada hakekatnya manusia menjadi subjek dan objek perubahan serta mempunyai sifat resisten terhadap perubahan. Oleh karena itu, perubahan sumber daya manusia perlu dimulai dengan melakukan pencairan terhadap pola perilaku lama yang cendrung mempertahankan keadaan untuk diubah agar bersedia menerima pola pikir baru yang berkembang secara dinamis.

\section{b. Indikator Kesiapan Individu Untuk Berubah}

Holt, et.al (2007) mengemukakan ada 4 dimensi kesiapan karyawan untuk berubah, yaitu sebagai berikut:

1) Appropriateness (Ketepatan untuk melakukan perubahan)

Dimensi ini menjelaskan tentang aspek keyakinan individu bahwa perubahan yang diajukan akan tepat bagi organisasi dan organisasi akan mendapat keuntungan dari penerapan perubahan.

2) Change specifik efficecy (Rasa percaya terhadap kemampuan diri untuk berubah) 
Dimensi ini menjelaskan aspek keyakinan individu tentang kemampuannya untuk menerapkan perubahan yang diinginkan, dimana ia merasa mempunyai ketrampilan serta sanggup untuk melakukan tugas yang berkaitan dengan perubahan.

3) Management support (Dukungan manajemen)

Dimensi ini menjelaskan aspek keyakinan atau persepsi individu bahwa para pemimpin atau manajemen akan mendukung dan berkomitmen terhadap perubahan yang diusulkan. Dengan kata lain, karyawan merasa bahwa pemimpin dan manajemen dalam organisasi memiliki komitmen dan mendukung pelaksanaan perubahan yang diusulkan.

4) Personal benefit (Manfaat bagi individu)

Dimensi ini menjelaskan aspek keyakinan mengenai keuntungan yang dirasakan secara personal yang akan didapatkan apabila perubahan tersebut diimplementasikan. Dengan kata lain karyawan merasa bahwa ia akan memperoleh manfaat dari pelaksanaan perubahan yang diusulkan.

\section{c. Komitmen Afektif}

Menurut Kaswan (2012: 293) “Komitmen afektif menunjukkan kuatnya keinginan emosional karyawan untuk beradaptasi dengan nilai-nilai yang ada agar tujuan dan keinginannya untuk tetap di organisasi dapat terwujud. Komitmen afektif dapat timbul pada diri seorang karyawan dikarenakan adanya karakteristik individu, karakteristik struktur organisasi, signfikansi tugas, berbagai keahlian, umpan balik dari pemimpin, dan keterlibatan dalam manajemen." Umur dan lama masa kerja di organisasi sangat berhubungan positif dengan komitmen afektif. Karyawan yang memiliki komitmen afektif akan cenderung untuk tetap dalam satu organisasi karena mereka mempercayai sepenuhnya misi yang dijalankan oleh organisasi. Komitmen afektif berkaitan dengan emosional, identifikasi, dan keterlibatan karyawan di dalam suatu organisasional. Karyawan dengan afektif tinggi masih bergabung dengan organisasi karena keinginan untuk tetap menjadi anggota organisasi (Allen dan Meyer, 1997). Komitmen afektif menyatakan bahwa organisasi akan membuat karyawan memiliki keyakinan yang kuat untuk mengikuti segala nilai-nilai organisasi, dan berusaha unutk mewujudkan tujuan organisasi sebagai prioritas utama. Komitmen afektif muncul karena kebutuhan, dan memandang bahwa komitmen terjadi karena adanya ketergantungan terhadap aktivitasaktivitas yang telah dilakukan dalam organisasi pada masa lalu dan hal ini tidak dapat ditinggalkan karena akan merugikan.

\section{d. Indikator Komitmen Afektif}

Adapun indikator komitmen affektif yang dapat digunakan dalam penelitian ini yang mengacu pada pendapat Allen dan Meyer (1997), yaitu:

1) Karyawan senang menghabiskan karir di perusahaan.

2) Karyawan senang membicarakan perusahaan besama rekan kerja saat sedang tidak bekerja.

3) Karyawan merasa masalah yang dihadapi perusahaan adalah masalah karyawan juga.

4) Karyawan merasa mudah beradaptasi saat bekerja di perusahaan.

5) Karyawan merasa bahwa perusahaan dan orang-orang di dalamnya seperti bagian dari keluarga karyawan sendiri. 
6) Karyawan merasa sangat menyatu secara emosional dengan perusahaan.

7) Perusahaan memiliki makna mendalam bagi karyawan

8) Karyawan merasa menjadi bagian dari perusahaan.

\section{e. Kepemimpinan Transformasional}

Menurut Jung dan Virgin Group (dalam Robbins, 2006:472), "Pemimpin transformasional memperhatikan hal-hal kebutuhan pengembangan dari masing-masing para pengikut dan persoalan-persoalan dengan membantu mereka memandang masalah lama dengan cara-cara baru, dan mereka mampu menggairahkan, membangkitkan, dan mengilhami para pengikut untuk mengeluarkan upaya ekstra demi mencapai sasaran kelompok."

Menurut Bass (1985 dalam Yukl, 2010:313) menjelaskan bahwa kepemimpinan transformasional adalah suatu keadaan dimana para pengikut dari seorang pemimpin transformasional merasa adanya kepercayaan, kekaguman, kesetiaan, dan hormat terhadap pemimpin tersebut, dan mereka termotivasi untuk melakukan lebih dari pada yang awalnya diharapkan mereka. Pemimpin tersebut mentransformasi dan memotivasi para pengikut dengan cara membuat mereka lebih sadar mengenai pentingnya hasil - hasil suatu pekerjaan, mendorong mereka untuk lebih mementingkan organisasi atau tim daripada kepentingan diri sendiri, dan mengaktifkan kebutuhan - kebutuhan mereka pada yang lebih tinggi.

\section{f. Indikator Kepemimpinan Transformasional}

Menurut Bass dan Avolio (1994), bahwa kepemimpinan transformasional dapat di ukur dengan dimensi berikut ini:

1) Attributed Charisma

Pemimpin mendahulukan kepentingan perusahaan dan kepentingan orang lain dari kepentingan diri. Ia sebagai pimpinan perusahaan bersedia memberikan pengorbanan untuk kepentingan perusahaan. Ia menimbulkan kesan pada bawahannya bahwa ia memiliki keahlian untuk melakukan tugas pekerjaannya, sehingga patut dihargai. Bawahan memiliki rasa bangga dan merasa tenang berada dekat dengan pemimpinnya. Pemimpin juga dapat tenang menghadapi situasi yang kritikal dan yakin dapat berhasil mengatasinya.

2) Inspirational Motivation

Pemimpin transformasional berperilaku dengan tujuan untuk memberi motivasi dengan inspirasi terhadap orang-orang disekitarnya. Pemimpin pandai dalam menyerukan visi masa depan, menantang para pengikutnya dengan standar yang tinggi, berbicara secara optimis dan antusias, dan memberikan dorongan dan arti dari apa yang perlu dilakukan.

3) Intellectual Stimulation

Pemimpin transformasional menstimulasi usaha bawahannya untuk berlaku inovatif dan kreatif dengan mempertanyakan asumsi, pembatasan masalah dan pendekatan dari situasi lama dengan cara yang baru.

4) Individualized Consideration

Pemimpin transformasional memiliki perhatian khusus terhadap kebutuhan individu dalam pencapaiannya dan pertumbuhan yang mereka harapkan dengan berperilaku sebagai pelatih atau mentor. 


\section{g. Iklim Psikologis}

Brown dan Leigh (dalam Yekty, 2006:32) menjelaskan bahwa iklim psikologis menunjukkan kepada bagaimana lingkungan organisasi dipersepsikan dan diinterprestasikan oleh karyawan. Sedangkan Solomon et al., (dalam Yekty,2006:32) menambahkan bahwa iklim psikologis merupakan interpretasi kognitif individu atas situasi dalam organisasi, dimana melalui iklim dapat diperoleh petunjuk mengenai harapan organisasi atas perilaku sehingga individu kemudian berusaha mengatur tingkah laku agar sesuai dengan yang diharapkan. Iklim psikologis menggambarkan iklim yang ada di perusahaan yang menyebabkan karyawan menyukai pekerjaan mereka dengan sepenuh hati atau justru dapat menimbulkan hambatan secara psikologis dengan pekerjaan mereka. Kahn (1990 dalam Suratman, 2016:5). Iklim psikologis menangkap makna representasi psikologis yang dibuat oleh individu secara relatif terhadap struktur, proses, dan peristiwa yang terjadi dalam organisasi (O'Neill dan Arend, 2008 dalam Suratman, 2016:5).

\section{h. Indikator Iklim Psikologis}

Menurut Yekty, (2006:48), bahwa iklim psikologis dapat diukur dengan indikator yaitu adanya dukungan, otonomi, pengakuan, kohesi, dan inovasi, berikut ini dapat dijelaskan:

1) Dukungan adalah sikap manajemen untuk memotivasi dan memberi semangat pada karyawan.

2) Otonomi adalah Kesempatan dalam menentukan sendiri cara kerja atau yang menyangkut pekerjaan

3) Pengakuan adalah sikap pimpinan yang menghargai upaya para karyawan dalam melakukan pekerjaan.

4) Kohesi adalah suatu keadaan yang berhubungan dengan situasi dan kondisi di sekitar lingkungan pekerjaan.

5) Inovasi adalah suatu kemauan dari karyawan dalam mengembangkan ide-ide pada pekerjaan.

\subsection{Hubungan Antar Variabel dan Pengembangan Hipotesis}

2.2.1. Pengaruh Kepemimpinan Transformasional Terhadap Kesiapan Individu Untuk Berubah

Kepemimpinan transformasional merupakan kepemimpinan yang melibatkan perubahan dalam organisasi. Menurut Northouse (2013) Kepemimpinan transformasional merupakan proses dimana orang terlibat dan menciptakan hubungan yang meningkatkan dorongan dalam diri individu dan moralitas dalam diri pemimpin. Sedangkan Natsir (2004) kepemimpinan transformasional berkenaan dengan pengaruh pemimpin atau atasan terhadap bawahan. Para bawahan merasakan adanya kepercayaan, kebanggaan, kesetiaan dan rasa hormat kepada atasan dan mereka termotivasi untuk melakukan melebihi apa yang diharapkan. Holt, et.al (2007) menyatakan, bahwa kesiapan berubah adalah kepercayaan karyawan bahwa mereka mampu melaksanakan perubahan yang diusulkan (self efficacy), perubahan yang diusulkan tepat untuk dilakukan organisasi (appropiateness), pemimpin berkomitmen dalam perubahan yang diusulkan (management support), dan perubahan yang diusulkan akan memberikan keuntungan bagi anggota organisasi (personal benefit). Dari penjelasan Holt, et.al bahwa seorang karyawan yang dinyatakan siap untuk berubah akan menunjukkan perilaku menerima, merangkul, dan mengadopsi rencana perubahan yang dilakukan. Oleh karena itu, dari pandangan beberapa para ahli dapat 
diduga bahwa kepemimpinan transformasional berpengaruh terhadap kesiapan individu untuk berubah. Hal tersebut di perkuat beberapa penelitian yaitu Santhidran, et.al (2010), Yuni (2014), Puspitasari (2015) dan Suryati (2016) membuktikan bahwa kepemimpinan transformasional berpengaruh terhadap kesiapan individu untuk berubah.

$\mathrm{H}_{1}$ : Diduga Kepemimpinan Transformasional berpengaruh signifikan terhadap Kesiapan Untuk Berubah pegawai Puskesmas Kabupaten Lombok Barat.

\subsubsection{Pengaruh Kepemimpinan Transformasional terhadap Komitmen Afektif}

Keinginan untuk berubah pada sebuah organisasi sangat ditentukan oleh komitmen afektif yang merupakan salah satu dimensi dari komitmen organisasi. Karyawan yang memiliki komitmen afektif akan cenderung untuk tetap dalam satu organisasi karena mereka mempercayai sepenuhnya misi yang dijalankan oleh organisasi. Menurut Kaswan (2012: 293) “ Komitmen afektif menunjukkan kuatnya keinginan emosional karyawan untuk beradaptasi dengan nilai-nilai yang ada agar tujuan dan keinginannya untuk tetap di organisasi dapat terwujud. Komitmen afektif dapat timbul pada diri seorang karyawan dikarenakan adanya karakteristik individu, karakteristik struktur organisasi, signfikansi tugas, berbagai keahlian, keterlibatan dalam manajemen dan umpan balik dari pemimpin". Apabila kepemimpinan yang ada mampu memaksimalkan seluruh sumberdaya yang dimiliki organisasi dapat diberdayakan secara optimal dalam melaksanakan programprogram perubahan. Melalui kepemimpinan transfomasional ini organisasi akan dapat meningkatkan dan menumbuhkan keberpihakan karyawan terhadap pekerjaan dan organisasinya. Pemberdayaan yang diberikan pimpinan mengandung makna meningkatnya beban tugas dan tanggung jawab dari setiap individu dalam melakukan perubahan untuk mencapai tujuan dari organisasi (Yukl, 2010). Hasil penelitian Dunn et.al di dukung oleh Irawati dan Liana (2013) menunjukkan kepemimpinan transformasional berpengaruh signifikan terhadap komitmen organisasi pada Karyawan PT Dos Ni Roha. Sedangkan penelitian Saeed, et.al (2013). Rashed and Daud (2013), Chou (2013), Kala, et.al (2015) membuktikan bahwa kepemimpinan transformasional berpengaruh terhadap komitmen afektif.

$\mathrm{H}_{2}$ : Diduga Kepemimpinan Transformasional berpengaruh signifikan terhadap Komitmen Afektif pegawai Puskesmas Kabupaten Lombok Barat.

\subsubsection{Pengaruh Kepemimpinan Transformasional terhadap Kesiapan Untuk Berubah melalui Komitmen Afektif pegawai Puskesmas Kabupaten Lombok Barat.}

Gaya kepemimpinan transformasional merupakan hal penting yang menjadi bentuk kesiapan berubah dalam level lindividu. Pemimpin transformasional akan mempengaruhi bawahan melalui perilaku-perilaku yang mampu menciptakan komitmen afektif dan motivasi intrinsik karyawan untuk melaksanakan agenda perubahan. Karyawan yang siap untuk berubah akan percaya bahwa organisasi akan mengalami kemajuan apabila organisasi melakukan perubahan, selain itu mereka memiliki sikap positif terhadap perubahan organisasi dan memiliki keinginan untuk terlibat dalam pelaksanaan perubahan organisasi (Armenakis, Harris dan Mossholder, 1993). Sebaliknya, apabila para karyawan tidak siap untuk berubah, maka mereka tidak akan dapat mengikuti dan merasa kewalahan dengan kecepatan perubahan organisasi yang sedang terjadi (Hanpacern et al, 1998). 


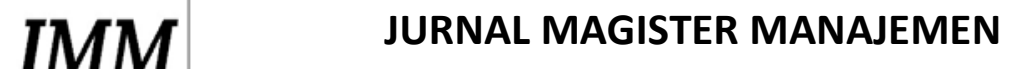 UNIVERSITAS MATARAM

Penelitian Rafferty et al., (2013) menyebutkan peran penting kepemimpinan dalam menciptakan kesiapan pegawai untuk menghadapi perubahan. Kepemimpinan tersebut tercermin dalam perilaku kepemimpinan yang sering disebut sebagai gaya kepemimpinan. Salah satu gaya kepemimpinan yang mempengaruhi kesiapan untuk berubah adalah gaya kepemimpinan transformasional (Palmer et al., 2009 dan Rafferty et al., 2013). Penelitian yang dilakukan oleh Suryati (2016), mengkaji komitmen organisasi sebagai variabel intervening terhadap Kesiapan Individu Untuk Berubah dan kepemimpinan transformasional adalah variabel independen yang secara langsung berpengaruh terhadap kesiapan individu untuk berubah. Hasil penelitian membuktikan kepemimpinan transformasional secara langsung berpengaruh terhadap kesiapan individu untuk berubah melalui komitmen organisasi.

$\mathrm{H}_{3}$ : Diduga Kepemimpinan Transformasional berpengaruh signifikan terhadap Kesiapan

Untuk Berubah melalui Komitmen Afektif pegawai Puskesmas Kabupaten Lombok Barat.

\subsubsection{Pengaruh Iklim Psikologis Terhadap Kesiapan Individu Untuk Berubah}

Penelitian yang dilakukan oleh Martin, dkk (2005) tentang The role of psychological climate in facilitating employee adjustment during organizational change. Menunjukan bahwa pegawai-pegawai yang mempersepsikan organisasi dan lingkungan kerja secara positif lebih mudah untuk mengikuti perubahan. Sedangkan penelitian yang dilakukan oleh Periantolo dan Mansoer, (2014) tentang faktor-faktor yang mempengaruhi kesiapan untuk berubah dengan mengkaji variabel keadilan organisasi, komitmen organisasi, dukungan organisasi dan iklim psikologis. Hasil penelitian membuktikan bahwa keadilan organisasi, dukungan organisasi dan iklim psikologis berpengaruh terhadap kesiapan untuk berubah. Namun variabel komitmen organisasi tidak berpengaruh terhadap kesiapan untuk berubah.

Penelitian yang dilakukan oleh Hasanah (2016) tentang pengaruh kepemimpinan transformasional dan iklim psikologis terhadap kesiapan untuk berubah pada pegawai Pengadilan Tinggi Yogyakarta membuktikan bahwa kepemimpinan transformasional berpengaruh positif namun tidak signifikan terhadap kesiapan untuk berubah dan Iklim psikologis berpengaruh positif dan signifikan terhadap kesiapan untuk berubah.

$\mathrm{H}_{4}$ : Diduga Iklim Psikologis berpengaruh signifikan terhadap Kesiapan Untuk Berubah pegawai Puskesmas Kabupaten Lombok Barat.

\subsubsection{Pengaruh Iklim Psikologis terhadap Komitmen Afektif}

Parker et al., (2003) mengatakan bahwa iklim psikologis mempunyai variasi hubungan dengan perilaku organisasi karyawan, sala satunya adalah komitmen organisasi. Penilaian iklim psikologis organisasi setiap karyawan berbeda-beda karena dinilai melalui persepsinya masing-masing. Iklim psikologis organisasi tersebut mempengaruhi sikap dan perilaku pada karyawan yang terwujud antara lain dalam komitmen karyawan pada organisasi (organizational commitment) (Gibson, Ivancevich, dan Donnelly, 2000:7).

Parker et al. (2003) menyatakan bahwa iklim psikologis mempunyai hubungan kuat dengan perilaku organisasi karyawan, diantaranya kepuasan kerja, komitmen organisasi, keterlibatan kerja, motivasi karyawan dan kinerja karyawan. Dari pandangan Parker, et.al dapat diperkuat oleh penelitian yang dilakukan oleh Sahin (2011), Logahan dan Rahman 
(2015) serta Suratman (2016) membuktikan bahwa iklim psikologis berpengaruh terhadap komitmen afektif.

$\mathrm{H}_{5}$ : Diduga Iklim Psikologis berpengaruh signifikan terhadap Komitmen Afektif pegawai Puskesmas Kabupaten Lombok Barat.

\subsubsection{Pengaruh Iklim Psikologis terhadap Kesiapan Untuk Berubah melalui Komitmen Afektif.}

Madson (dalam Periantolo dan Mansoer, 2014), menyatakan bahwa kesiapan untuk berubah adalah sebagai sekumpulan pemikiran dan kemauan individu untuk menghadapi perubahan tertentu, dan perubahan yang terjadi akan membawa dampak kepada karyawan, bagi yang siap dengan perubahan akan bersemangat mengikuti perubahan.

Menurut Meyer dan Herscovitch (dalam Coetzee, 2005), Setiap pegawai memiliki dasar dan tingkah laku yang berbeda berdasarkan komitmen organisasi yang dimilikinya. Pegawai yang memiliki komitmen organisasi dengan dasar afektif memiliki tingkah laku berbeda dengan karyawan yang berdasarkan continuance dan normative. Pegawai dengan affective commitment yang tinggi memiliki kedekatan emosional yang erat terhadap organisasi. Hal ini berarti bahwa individu tersebut akan memiliki motivasi dan keinginan untuk berkontribusi secara berarti terhadap organisasi.

Penelitian yang dilakukan oleh Anggi, (2014), dan Sahin, (2011), membuktikan bahwa komitmen sebagai variabel intervening dan iklim psikologis sebagai variabel indipenden berpengaruh terhadap kesiapan individu untuk berubah.

$\mathrm{H}_{6}$ : Diduga Iklim Psikologis berpengaruh signifikan terhadap Kesiapan Untuk Berubah melalui Komitmen Afektif pegawai Puskesmas Kabupaten Lombok Barat.

\subsubsection{Pengaruh Komitmen Afektif terhadap Kesiapan Individu Untuk Berubah}

Weiner (2009:1) mengungkapkan bahwa kesiapan untuk berubah dalam organisasi mengacu pada tekat bersama anggota organisasi untuk mengimplementasikan perubahan (komitmen untuk berubah) serta kepercayaan bersama bahwa mereka mampu melakukan perubahan tersebut (efikasi untuk berubah). Sedangkan komitmen organisasi diartikan sebagai identifikasi pegawai terhadap organisasi dan kemauan untuk tetap bersama organisasi. Pegawai yang mempunyai komitmen tinggi terhadap organisasi akan memberikan pemikiran dan tenaganya untuk organisasi. Kemajuan organisasi adalah kemajuan pegawai.

Beberapa penelitian terdahulu membuktikan bahwa komitmen afektif berpengaruh terhadap kesiapan individu untuk berubah. Dimana penelitian yang dilakukan oleh Sahin (2011), Pramadani dan Fajrianthi (2012), Zulkarnain dan Hadiyani (2014) membuktikan bahwa komitmen afektif berpengaruh terhadap kesiapan individu untuk berubah.

$\mathrm{H}_{7}$ : Diduga Komitmen Afektif berpengaruh signifikan terhadap Kesiapan Untuk Berubah pegawai Puskesmas Kabupaten Lombok Barat.

Berdasarkan fenomena, penelitian terdahulu dan landasan teori di atas, maka disusun kerangka konseptual sebagai berikut : 


\section{JMM

\section{Gambar 1. Kerangka Konseptual}

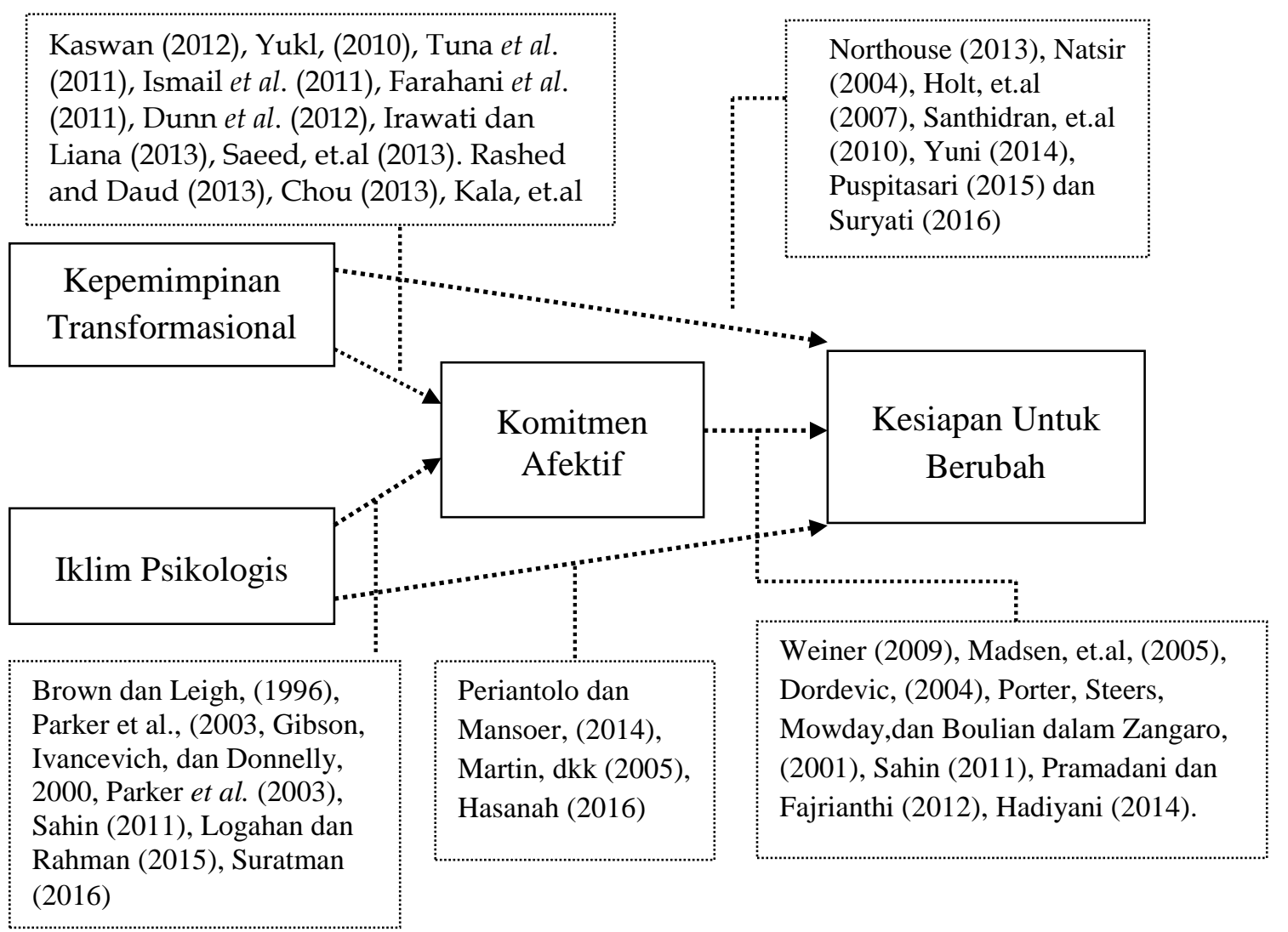

\section{METODE PENELITIAN}

Sesuai dengan perumusan masalah dan tujuan yang dilakukan maka jenis penelitian yang digunakan dalam penelitian ini adalah penelitian kausal. Populasi dalam penelitian ini adalah seluruh pegawai/karyawan-karyawati yang ada di 7 Puskesmas yang belum terakreditasi di wilayah Kabupaten Lombok Barat dengan jumlah 508. Karena banyaknya populasi, maka sampel sebanyak 84 secara Proportional Random Sampling mengguanakn rumus slovin. Pengambilan sampel secara proporsi dimana semua individu dalam populasi, baik secara sendiri-sendiri atau bersama-sama diberi kesempatan yang sama untuk dipilih menjadi anggota sampel.

Teknik analisis data menggunakan analisis Jalur. Analisis Jalur adalah suatu teknik pengembangan dari regresi linier ganda.Teknik ini digunakan untuk menguji besarnya sumbangan (kontribusi) yang ditunjukkan oleh koefisien jalur pada setiap diagram jalur dari hubungan kausal antar variabel $X$ terhadap $Y$ serta dampaknya terhadap $Z$. "Analisis jalur ialah suatu teknik untuk menganalisis hubungan sebab akibat yang tejadi pada regresi berganda jika variabel bebasnya mempengaruhi variabel tergantung tidak hanya secara langsung tetapi juga secara tidak langsung". (Retherford dalam Sarwono 2007:1).

\section{HASIL PENELITIAN DAN PEMBAHASAN}

\subsection{Karakristik Responden}

Responden terbanyak adalah pada kelompok umur 31-40 tahun yaitu 41 orang karyawan atau $49 \%$. Sedangkan kelompok umur yang paling sedikit adalah kelompok 


\section{JMM

umur $>40$ tahun sebanyak 4 orang karyawan atau $17 \%$ dari $100 \%$ atau 84 orang karyawan secara keseluruhan yang berada di 7 Puskesmas. Hal ini menunjukkan bahwa umur responden ditemukan rata-rata karyawan memiliki usia 31-40 tahun, dimana umur 31-40 yang dominan dalam memberikan banyak tanggapan terhadap komitmen afektif dan kesiapan untuk berubah karyawan Puskesmas Kabupaten Lombok Barat. Responden sebagian besar berjenis kelamin perempuan, yaitu sebanyak 51 orang karyawan atau $61 \%$ dan sisanya adalah responden yang berjenis kelamin laki-laki, yaitu sebanyak 33 orang karyawan atau $39 \%$. Jadi pada penelitian ini lebih dominan responden perempuan dari pada responden laki-laki yang memiliki persentase yang dominan di Puskesmas Kabupaten Lombok Barat yang memberikan tanggapan tentang kepemimpinan transformasional, iklim psikologis, komitmen afektif dan kesiapan untuk berubah. Hal ini terjadi karena jumlah karyawan Puskesmas Kabupaten Lombok Barat yang berjenis kelamin perempuan lebih banyak dibandingkan jumlah karyawan laki-laki yang dijumpai pada waktu penyebaran kuesioner.

Responden berpendidikan Diploma III, yaitu sebanyak 46 orang karyawan atau $55 \%$. Sedangkan responden yang mempunyai tingkat pendidikan Diploma IV dan Sarjana tingkat 2 atau (S 2) adalah yang terkecil, yaitu masing-masing sebanyak 1 orang karyawan atau 1\% dari 84 atau 100 keseluruhan karyawan Puskesmas Kabupaten Lombok Barat. Jadi yang lebih dominan terlihat tingkat pendidikan Diploma III. Pada tingkat pendidikan Diploma III ini, peneliti menemukan kebanyakan yang dijumpai pada waktu penyebaran kuesiner terlihat pada tingkat Diploma III yang terdiri dari Bidan dan sebagiannya adalah Perawat. Responden dalam penelitian ini memiliki masa kerja yang berbeda-beda, dimana hasil temuan menunjukkan bahwa masa kerja karyawan Puskesmas Kabupaten Lombok Barat banyak memiliki masa kerja 6-15 tahun sebanyak 39 orang karyawan atau $46 \%$. Sedangkan masa kerja lebih dari 26 tahun adalah yang terkecil sebanyak 7\% atau 6 orang karyawan. Dari masa kerja karyawan tersebut, menunjukkan masa kerja yang cukup lama dalam mengabdikan diri sebagai anggota organisasi. Jadi dapat dilihat bahwa sebagaian besar karyawan Puskesmas memiliki masa kerja yang cukup lama, artinya bahwa keanggotaannya dalam organisasi sudah melekat dalam diri karyawan yang selalu menunjukkan adanya komitmen bersama untuk mempersiapkan diri pada perubahan akreditasi yang akan dilaksanakan.

\subsection{Analisis Data}

Berdasarkan model-model pengaruh yang sudah dijelaskan di atas, maka dapat dibuat model lintasan pengaruh analisis path secara keseluruhan, yang merupakan gabungan antara lintasan pengaruh langsung variabel kepemimpinan transformasional $\left(X_{1}\right)$ dan iklim psikologis $\left(X_{2}\right)$ terhadap komitmen afektif $(Z)$, ditambah variabel kepemimpinan transformasional $\left(X_{1}\right)$, iklim psikologis $\left(X_{2}\right)$ terhadap kesiapan individu untuk berubah $(\mathrm{Y})$, seperti terlihat berikut ini. 
Gambar 2.

Model Gabungan Lintasan Koefisien Jalur Signifikansi Pengaruh Variabel Kepemimpinan Transformasional dan Iklim Psikologis terhadap Kesiapan Individu Untuk Berubah melalui Komitmen Afektif

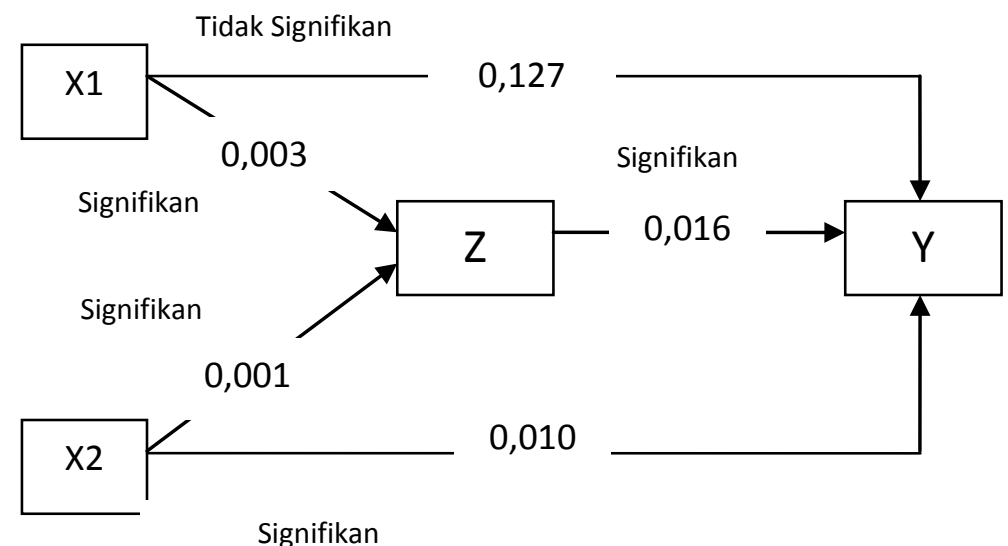

Signifikan

$$
\begin{aligned}
& Y=\operatorname{Pyx}_{1} X_{1}+\operatorname{Pyx}_{2} X_{2}+\operatorname{Pyz} Y+\operatorname{Py} \varepsilon_{1} \\
& Z=\operatorname{Pzx}_{1} X_{1}+\operatorname{Pzx}_{2} X_{2}+\operatorname{Pz} \varepsilon_{2}
\end{aligned}
$$

Dari gambar model penelitian di atas, dapat dilihat besarnya pengaruh antar variabel yang ditunjukkan oleh nilai-nilai yang ada pada setiap lintasan koefisien jalur. Dari hasil penelitian di atas, maka dijelaskan bahwa:

a) Kepemimpinan Transformasional berpengaruh positif dan tidak signifikan terhadap Kesiapan Untuk Berubah karyawan Puskesmas Kabupaten Lombok Barat dengan besar koefisien jalur 0,127.

b) Kepemimpinan Transformasional berpengaruh positif dan signifikan terhadap Komitmen Afektif karyawan Puskesmas Kabupaten Lombok Barat. Artinya bahwa semakin efktif penerapan gaya Kepemimpinan Transformasional dengan besar koefisien jalur 0,003 .

c) Terdapat pengaruh positif dan signifikan Kepemimpinan Transformasional terhadap Kesiapan Untuk Berubah melalui Komitmen Afektif karyawan Puskesmas Kabupaten Lombok Barat.

d) Iklim Psikologis berpengaruh positif dan signifikan terhadap Kesiapan Untuk Berubah karyawan Puskesmas Kabupaten Lombok Barat dengan besar koefisien jalur 0,010.

e) Iklim Psikologis berpengaruh positif dan signifikan terhadap Komitmen Afektif karyawan Puskesmas Kabupaten Lombok Barat dengan besar koefisien jalur 0,001.

f) Terdapat pengaruh positif dan signifikan Iklim Psikologis terhadap Kesiapan Untuk Berubah melalui Komitmen Afektif karyawan Puskesmas Kabupaten Lombok Barat.

g) Komitmen Afektif berpengaruh positif dan signifikan terhadap Kesiapan Untuk Berubah karyawan Puskesmas Kabupaten Lombok Barat dengan besar koefisien jalur 0,016 . 


\section{PEMBAHASAN HASIL PENELITIAN}

5.1. Pengaruh Kepemimpinan Transformasional terhadap Kesiapan Untuk Berubah pegawai Puskesmas Kabupaten Lombok Barat.

Hipotesis penelitian menyatakan bahwa kepemimpinan transformasional berpengaruh signifikan terhadap kesiapan untuk berubah. Namun hasil penelitian ini menunjukkan bahwa kepemimpinan transformasional berpengaruh tidak signifikan terhadap kesiapan untuk berubah pegawai Puskesmas Kabupaten Lombok Barat, sehingga hipotesis yang diajukan ditolak atau tidak diterima. Hasil ini tidak mendukung sebagian besar hasil penelitian terdahulu yang menemukan bahwa kepemimpinan transformasional berpengaruh signifikan terhadap kesiapan untuk berubah (misalnya Santhidran, et.al (2010), Yuni (2014), Puspitasari (2015) dan Suryati (2016). Menurut Kreitner dan Kinicki, (2014), Seorang pemimpin yang transformasional akan mampu memberikan hasil perubahan organisasi yang signifikan melalui perilaku memimpin yang mampu meningkatkan motivasi intrinsik, kepercayaan, komitmen, dan loyalitas dari bawahan.

Peneltian yang dilakukan oleh Yuni (2014) dengan mengkaji pengaruh gaya kepemimpinan terhadap kesiapan berubah, serta menguji dan menganalisis apakah komitmen organisasional merupakan variabel pemoderasi yang mempengaruhi gaya kepemimpinan terhadap kesiapan berubah. Hasil penelitian bahwa gaya kepemimpinan transformasional mempengaruhi kesiapan berubah, dan komitmen organisasional memoderasi pengaruh gaya kepemimpinan transformasional terhadap kesiapan berubah. Hasil penelitian Yuni dapat dipertegas oleh Zulkarnain \& Hadiyani (2014) dan Suryati (2016) dalam hasil penelitiannya membuktikan bahwa kepemimpinan transformasional dan komitmen organisasi berpengaruh signifikan terhadap kesiapan untuk berubah.

\subsection{Pengaruh Kepemimpinan Transformasional terhadap Komitmen Afektif pegawai Puskesmas Kabupaten Lombok Barat.}

Hasil penelitian ini membuktikan bahwa Kepemimpinan Transformasional berpengaruh signifikan terhadap Komitmen Afektif pegawai Puskesmas Kabupaten Lombok Barat. Hasil penelitian ini sesuai dengan hasil penelitian yang dilakukan oleh Dunn et.al di dukung oleh Irawati dan Liana (2013) menunjukkan kepemimpinan transformasional berpengaruh signifikan terhadap komitmen organisasi pada Karyawan PT Dos Ni Roha. Sedangkan penelitian Saeed, et.al (2013). Rashed and Daud (2013), Chou (2013), Kala, et.al (2015) membuktikan bahwa kepemimpinan transformasional berpengaruh terhadap komitmen afektif. Keinginan untuk berubah pada sebuah organisasi sangat ditentukan oleh komitmen afektif yang merupakan salah satu dimensi dari komitmen organisasi. Karyawan yang memiliki komitmen afektif akan cenderung untuk tetap dalam satu organisasi karena mereka mempercayai sepenuhnya misi yang dijalankan oleh organisasi. Menurut Kaswan (2012: 293) “ Komitmen afektif menunjukkan kuatnya keinginan emosional karyawan untuk beradaptasi dengan nilai-nilai yang ada agar tujuan dan keinginannya untuk tetap di organisasi dapat terwujud. Komitmen afektif dapat timbul pada diri seorang karyawan dikarenakan adanya karakteristik individu, karakteristik struktur organisasi, signfikansi tugas, berbagai keahlian, keterlibatan dalam manajemen dan umpan balik dari pemimpin". 


\subsection{Pengaruh Kepemimpinan Transformasional terhadap Kesiapan Untuk Berubah} melalui Komitmen Afektif karyawan Puskesmas Kabupaten Lombok Barat.

Hasil penelitian ini membuktikan bahwa Kepemimpinan Transformasional berpengaruh signifikan terhadap Kesiapan Untuk Berubah melalui Komitmen Afektif karyawan Puskesmas Kabupaten Lombok Barat. Penelitian yang dilakukan oleh Suryati (2016), mengkaji komitmen organisasi sebagai variabel intervening terhadap Kesiapan Individu Untuk Berubah dan kepemimpinan transformasional adalah variabel independen yang secara langsung berpengaruh terhadap kesiapan individu untuk berubah. Hasil penelitian membuktikan kepemimpinan transformasional secara langsung berpengaruh terhadap kesiapan individu untuk berubah melalui komitmen organisasi.

Gaya kepemimpinan transformasional merupakan hal penting yang menjadi bentuk kesiapan berubah dalam level lindividu. Pemimpin transformasional akan mempengaruhi bawahan melalui perilaku-perilaku yang mampu menciptakan komitmen afektif dan motivasi intrinsik karyawan untuk melaksanakan agenda perubahan. Karyawan yang siap untuk berubah akan percaya bahwa organisasi akan mengalami kemajuan apabila organisasi melakukan perubahan, selain itu mereka memiliki sikap positif terhadap perubahan organisasi dan memiliki keinginan untuk terlibat dalam pelaksanaan perubahan organisasi (Armenakis, Harris dan Mossholder, 1993). Sebaliknya, apabila para karyawan tidak siap untuk berubah, maka mereka tidak akan dapat mengikuti dan merasa kewalahan dengan kecepatan perubahan organisasi yang sedang terjadi (Hanpacern et al, 1998).

\subsection{Pengaruh Iklim Psikologis terhadap Kesiapan Untuk Berubah karyawan Puskesmas Kabupaten Lombok Barat.}

Hasil penelitian ini membuktikan bahwa Iklim Psikologis berpengaruh signifikan terhadap Kesiapan Untuk Berubah karyawan Puskesmas Kabupaten Lombok Barat. Penelitian yang dilakukan oleh Martin, dkk (2005) tentang The role of psychological climate in facilitating employee adjustment during organizational change. Menunjukan bahwa pegawai-pegawai yang mempersepsikan organisasi dan lingkungan kerja secara positif lebih mudah untuk mengikuti perubahan.

Iklim psikologis adalah pandangan setiap individu terhadap lingkungan kerja. Pandangan individu yang positif mendukung terjadinya perubahan organisasi. Persepsi positif tersebut dapat berupa kebebasan individu dalam berekspresi di tempat kerja, peran/tugas yang jelas, pekerjaan yang di hargai oleh orang lain dan dukungan dari manajemen (Periantolo dan Mansoer, 2014:198). Hasil penelitian sesuai dengan penelitian yang dilakukan oleh Periantolo \& Mansoer, (2014) dan Hasanah (2016) membuktikan bahwa Iklim psikologis berpengaruh positif dan signifikan terhadap kesiapan karyawan untuk berubah.

\subsection{Pengaruh Iklim Psikologis terhadap Komitmen Afektif karyawan Puskesmas Kabupaten Lombok Barat.}

Hipotesis penelitian menduga bahwa "Iklim Psikologis berpengaruh signifikan terhadap Komitmen Afektif karyawan Puskesmas Kabupaten Lombok Barat". Hasil penelitian ini membuktikan bahwa Iklim Psikologis berpengaruh signifikan terhadap Komitmen Afektif karyawan Puskesmas Kabupaten Lombok Barat. Artinya semakin menyenangkan Iklim 


\section{IMM JURNAL MAGISTER MANAJEMEN UNIVERSITAS MATARAM

psikologis karyawan dan didukung dengan semakin tinggi komitmen afektif karyawan maka semakin baik karyawan dalam menerima perubahan organisasi.

Brown dan Leigh (dalam Yekty, 2006:32) menjelaskan bahwa iklim psikologis

menunjukkan kepada bagaimana lingkungan organisasi dipersepsikan dan diinterprestasikan oleh karyawan. Sedangkan Solomon et al., (dalam Yekty,2006:32) menambahkan bahwa iklim psikologis merupakan interpretasi kognitif individu atas situasi dalam organisasi, dimana melalui iklim dapat diperoleh petunjuk mengenai harapan organisasi atas perilaku sehingga individu kemudian berusaha mengatur tingkah laku agar sesuai dengan yang diharapkan. Jadi dapat dijelaskan bahwa iklim psikologis berpengaruh terhadap komitmen karyawan di organisasi. Hal ini didukung oleh beberapa penelitian yaitu Sahin (2011), Logahan dan Rahman (2015) serta Suratman (2016) membuktikan bahwa iklim psikologis berpengaruh terhadap komitmen afektif.

\subsection{Pengaruh Iklim Psikologis berpengaruh signifikan terhadap Kesiapan Untuk} Berubah melalui Komitmen Afektif pegawai Puskesmas Kabupaten Lombok Barat.

Hasil penelitian ini membuktikan bahwa Iklim Psikologis berpengaruh signifikan terhadap Kesiapan Untuk Berubah melalui Komitmen Afektif pegawai Puskesmas Kabupaten Lombok Barat. Artinya semakin menyenangkan Iklim psikologis karyawan dan didukung dengan semakin tinggi komitmen afektif karyawan maka semakin baik kesiapan untuk menerima perubahan dari karyawan.

Hasil penelitian ini didukung oleh beberapa penelitian (misalnya Anggi, 2014, dan Sahin, 2011, membuktikan bahwa komitmen sebagai variabel intervening dan iklim psikologis sebagai variabel indipenden berpengaruh terhadap kesiapan individu untuk berubah. Menurut Madson (dalam Periantolo dan Mansoer, 2014), menyatakan bahwa kesiapan untuk berubah adalah sebagai sekumpulan pemikiran dan kemauan individu untuk menghadapi perubahan tertentu, dan perubahan yang terjadi akan membawa dampak kepada karyawan, bagi yang siap dengan perubahan akan bersemangat mengikuti perubahan.

\subsection{Pengaruh Komitmen Afektif terhadap Kesiapan Untuk Berubah pegawai Puskesmas Kabupaten Lombok Barat.}

Hasil penelitian ini membuktikan bahwa komitmen afektif berpengaruh signifikan terhadap kesiapan untuk berubah karyawan Puskesmas Kabupaten Lombok Barat. Hasil penelitian ini didukung oleh penelitian yang dilakukan oleh beberapa penelitian terdahulu membuktikan bahwa komitmen afektif berpengaruh terhadap kesiapan individu untuk berubah. Dimana penelitian yang dilakukan oleh Sahin (2011), Pramadani dan Fajrianthi (2012), Zulkarnain dan Hadiyani (2014) membuktikan bahwa komitmen afektif berpengaruh terhadap kesiapan individu untuk berubah.

Weiner (2009:1) mengungkapkan bahwa kesiapan untuk berubah dalam organisasi mengacu pada tekat bersama anggota organisasi untuk mengimplementasikan perubahan (komitmen untuk berubah) serta kepercayaan bersama bahwa mereka mampu melakukan perubahan tersebut (efikasi untuk berubah). Sedangkan komitmen organisasi diartikan sebagai identifikasi pegawai terhadap organisasi dan kemauan untuk tetap bersama organisasi. Pegawai yang mempunyai komitmen tinggi terhadap organisasi akan memberikan pemikiran dan tenaganya untuk organisasi. Kemajuan organisasi adalah kemajuan pegawai. Masalah organisasi adalah masalah pegawai. Pegawai menerima nilai- 
nilai tujuan organisasi dan pegawai mendukung perkembangan organisasi serta pegawaipun siap dalam menghadapi perubahan di organisasi (Madsen, et.al, 2005).

\section{KESIMPULAN}

6.1. Kepemimpinan Transformasional berpengaruh positif dan tidak signifikan terhadap Kesiapan Untuk Berubah pegawai Puskesmas Kabupaten Lombok Barat.

6.2. Terdapat pengaruh positif dan signifikan Kepemimpinan Transformasional terhadap Komitmen Afektif pegawai Puskesmas Kabupaten Lombok Barat.

6.3. Terdapat pengaruh positif dan signifikan Kepemimpinan Transformasional terhadap Kesiapan Untuk Berubah melalui Komitmen Afektif pegawai Puskesmas Kabupaten Lombok Barat.

6.4. Terdapat pengaruh positif dan signifikan Iklim Psikologis terhadap Kesiapan Untuk Berubah pegawai Puskesmas Kabupaten Lombok Barat.

6.5. Terdapat pengaruh positif dan signifikan Iklim Psikologis terhadap Komitmen Afektif pegawai Puskesmas Kabupaten Lombok Barat.

6.6. Terdapat pengaruh positif dan signifikan Iklim Psikologis terhadap Kesiapan Untuk Berubah melalui Komitmen Afektif pegawai Puskesmas Kabupaten Lombok Barat.

6.7. Terdapat pengaruh positif dan signifikan Komitmen Afektif terhadap Kesiapan Untuk Berubah pegawai Puskesmas Kabupaten Lombok Barat.

\section{REKOMENDASI}

7.1. Hasil penelitian membuktikan bahwa kepemimpinan transformasional tidak berpengaruh signifikan secara langsung terhadap kesiapan individu untuk berubah. Artinya peran pemimpin untuk mempengaruhi secara langsung dalam mentransformasi isi dari pekerjaan dan memotivasi para karyawan di Puskesmas sangat kecil sekali atau tidak berarti (bermakna). Hal ini akan berarti penting jika pemimpin dapat menumbuhkan komitmen dalam diri karyawan sehingga terbentuk komitmen afektif atau secara emosional karyawan memiliki keinginan yang kuat dalam dirinya untuk mewujudkan keberhasilan implementasi akreditasi Puskesmas.

7.2. Untuk kepemimpinan kepala Puskesmas Kabupaten Lombok Barat sebagai pengambil keputusan dalam organisasi, agar mempertimbangkan langkah-langkah dalam meningkatkan kesiapan karyawan untuk berubah dikarenakan secara langsung tidak signifikan pengaruh pada karyawan dalam kesiapan berubah.

7.3. Untuk variabel iklim psikologis yang secara langsung berpengaruh terhadap kesiapan untuk berubah. Hal ini para karyawan dapat meningkatkan dalam hal "Membuat banyak keputusan yang mempengaruhi cara melakukan pekerjaannya sendiri, Dalam organisasi ini karyawan harus saling memperhatikan kepentingan satu samalain untuk kemajuan organisasi, selalu mengembangkan gagasan-gagasan baru untuk kesuksesan akreditasi Puskemas agar organisasi dapat mengakui pentingnya kontribusi karyawan.

7.4. Bagi para peneliti yang tertarik dengan judul yang sama dengan kajian pengaruh langsung dan tidak langsung menggunakan analisis jalur, sebaiknya memperhatikan hal-hal seperti subjek penelitian juga perlu diperluas dengan jumlah responden lebih besar sehingga ketepatan model dengan variasi pengaruhnya bisa lebih tinggi lagi dalam menemukan model yang optimal pada variabel dependen. 
Perlu dikaji ulang untuk variabel pengaruh kepemimpinan transformasional terhadap kesiapan individu untuk berubah dengan menambah variabel atau mengganti variabel yang akan berpengaruh terhadap variabel dependen seperti komitmen organisasi.

\section{DAFTAR PUSTAKA}

Allen, N. J. \& J. P. Meyer. 1997. Commitment in The Workplace Theory Research and Application. Califotnia: Sage Publications.

Anggi, I., 2014. "Analisis Pengaruh Kepemimpinan Transformasional dan Iklim Psikologis Pada Kesiapan Untuk Berubah". Tesis. Yogyakarta: Universitas Gadjah Mada

Armenakis, A.A., Harris, S.G., \& Mossholder, K.W., (1993), Creating Readiness for Change.

Bass, B.M., Avolio, B.J. (1994). Improving Organizational Effectiveness through Transformasional Leadership. Thousand Oaks : Sage.

Bouckenooghe, D. dan Devos, G. 2007. Psychological Change Climate as a Catalyst of Readiness for Change: Dominance Analysis. Working Paper, Limited Publication. Universitieit Gent, Faculteit Economie En Bedrijfskunde.

Cinite, I., Duxbury, L.E. and Higgins, C. (2009), "Measurement of perceived organizational readiness for change in the public sector", British Journal of Management, Vol. 20, pp. 265-77

Chou, P., (2013). "The Effect of Transformational Leadership on Follower's Affective Commitment to Change", World Journal of Social Sciences, 3 (1) : pp38-52.

Coetzee, M. 2005. Employee Commitment. University of Pretoria etd.

Dunn, M.W., Dastoor, B. and Sims, R.L. 2012. “Transformational Leadership and Organizational Commitment: A Cross-Cultural Perspective", Journal of Multidisciplinary Research, 4 (1): pp. 45-59.

Holt, D. T., Armenakis, A. A., Field, H. S., \& Harris, S. G. (2007). "Readiness for Organizational change: The systematic development of a scale". Journal of Applied Behavioral Science, 43(2): pp232-255

Hasanah, N., (2016), "Pengaruh Kepemimpinan Transformasional dan Iklim Psikologis terhadap Kesiapan Untuk Berubah Pegawai Pengadilan Tinggi Yogyakarta. Tesis Universitas Gadjah Mada Yogyakarta.

Irawati, R., dan Liana, Y., 2013. "Effect of Transformational Leadership Style and Job Satisfaction on Employee Performance With Organizational Commitment As Interval Variables". Jurnal Ilmiah ESAI, 7 (3): pp1978-6034. 
Kala, A., Lembang., Soetjipto, B.E., and Sutrisno., 2015, “The Effect of Transformational Leadership and Organizational Culture on Employees Working Performance Through Organizational Commitment", IJABER Journal, 13 (7): pp5305-5322.

Kaswan. 2012. Manajemen Sumber Daya Manusia Untuk Keunggulan Bersaing Organisasi. Cetakan Pertama. Yogyakarta : Graha Ilmu.

Logahan, J.M., dan Rahman, H., 2015, “Pengaruh Iklim Psikologis Terhadap Komitmen Afektif Yang Berdampak Pada OCB Karyawan di PT. Petrokimia Gresik", Jurnal Business Review, 6 (2): pp196-205.

Martin, A., Jones, E. and Callan, V. (2005). “The role of psychological climate in facilitating employee adjustment during organizational change". European Journal of Work and Organizational Psychology, 1 (14): pp. 263-89.

Northouse, Peter. G, 2013. Leadership Theory and Practice: Kepemimpinan Teori dan Praktek. Edisi keenam. PT. Indeks 2013, Jakarta.

Natsir, S., 2004. “Ringkasan Disertasi: Pengaruh Gaya Kepemimpinan Terhadap Perilaku Kerja dan Kinerja Karyawan Perbankan di Sulawesi Tengah". Disertasi, Universitas Airlangga Surabaya.

Periantolo, J., dan Mansoer, W.D., 2014, "Faktor-faktor Yang Mempengaruhi Kesiapan Untuk Berubah Pegawai di Dirjen PQR". Jurnal Psikologis, 14 (3) : pp195-203.

Palmer, I., et.al, 2009, Managing Organizational Change. New York, Amerika: McGrawhill.

Rashed, F., and Daud, K., 2013," Effects of Transformational leadership on Organizational Commitment at University Departmental Level", Journal International Seminar on Quality and Affordable Education (ISQAE).

Rafferty, A.E., Jimmieson, N.L., et.al. 2013, "Change Readiness: A Multilevel Review". Journal of Management, 39: pp110-135

Robbins, S.P., 2003. Perilaku Organisasi 10th ed. New Jersey: Prentice Hall.

Suratman, A., 2016, "Pengaruh Iklim Psikologi Terhadap Keterlibatan Kerja Melalui Komitmen Afektif Pada Pegawai Pendidikan Anak Usia Dini Di Kabupaten Sukoharjo", Jawa Tengah". Jurnal Manajemen Ekonomi, 7 (1): 7-21.

Sarwono, J. 2007. Analisis Jalur untuk Riset Bisnis dengan SPSS. Yogyakarta : Andi Offset.

Santhidran, S., Borromeo, H.M., and Chandran, V.G.R., 2010. "Enabling Change in Malaysia: Leadership, Commitment to Change, and The Mediating Role of Change Readiness. Jurnal Business and Development. 1 (3): pp1-23. 


\section{JMM

Suryati, H., 2016, "Pengaruh Kepuasan Kerja Dan Kepemimpinan Transformasional Terhadap Kesiapan Individu Untuk Berubah Dengan Komitmen Organisasi Sebagai Variabel Intervening (Studi Pada Dinas Pertanian Peternakan Perkebunan dan Kehutanan Kota Padang)". Tesis Universitas Bung Hatta.

Sahin, F., 2011, "Affective Commitment as a Mediator of the Relationship Between Psycological Climate and Turnover Intetion". World Applied Sciences Journal, 14 (4): pp523-530.

Saeed, R., Hashmi, A., Lodhi, R.N., Ahmad, M., Arshad, H.M., Ahmad, M.A., 2013, "The effect of Transformational Leadership on Organizational Commitment with a Mediating effect of Psychological Empowerment", Journal of Basic and Applied Scientific Research, 3 (6): pp28-36.

Wibowo. (2005). Managing Change: Pengantar Manajemen Perubahan. Bandung: Alfabeta.

Weiner, B. J. (2009). A theory of Organizational Readiness for Change. Implementation Science.

Yekty, R.P., 2006, "Analisis Pengaruh Iklim Psikologis Terhadap Keterlibatan Kerja Dan Kepuasan Kerja Dalam Meningkatkan Kinerja Karyawan (Studipada. PT. Coca Cola Bottling Indonesia Central Java Semarang)". Tesis Manajemen.

Yuni, G.T., (2014), "Pengaruh Gaya Kepemimpinan Terhadap Kesiapan Berubah Dengan Komitmen Organisasional Sebagai Variabel Pemoderasi Studi Pada BPJS Ketenagakerjaan Cabang Yogyakarta. Tesis Universitas Gadjah Mada Yogyakarta.

Yukl, G., 2010. Kepemimpinan dalam Organisasi, Edisi Kelima. Jakarta: PT, Indeks.

Zulkarnain, dan Hadiayanti, S., 2014, "Peranan Komitmen Organisasi dan Employee Engagement terhadap Kesiapan Karyawan untuk Berubah". Jurnal Psikologi, 41 (1): pp19-35. 